\title{
News Framing on Malay Deli Culture in medan.tribunnews.com Online Media
}

\author{
Rudianto $^{1)}$ Akhyar Anshori 2,a) \\ ${ }^{1}$ Universitas Muhammadiyah Sumatera Utara \\ ${ }^{2}$ Universitas Muhammadiyah Sumatera Utara \\ a) akhyaransori@umsu.ac.id
}

DOI: https://doi.org/10.18196/jkm.122041

\section{Article Info}

Article history: Received 9 Sep 2020 Revised 16 Nov 2020 Accepted 24 Nov 2020

\section{ABSTRACT}

This article aims to analyze how the frame of online media coverage in Medan on Malay Culture. The identity of Ethnic Malay Culture in Medan can be found in several buildings that become icons of Medan city such as Maimon Palace and Masjid Raya Al Mahsun located in the center of Medan City. In addition to having various icons related to Malay, Medan is also a city with native Malay people. Along with the stream of globalization, Malay Culture is increasingly widely recognized by the community or public through the mass media, mainly online media in Medan. This research was conducted through a qualitative approach with a constructivist paradigm through Entman framing model analysis method. The results of this article are that the online media in Medan in this case www.medan.tribunnews.com gives a wide space in spreading Malay Culture in Medan. Three findings are related to the reporting themes, government and community involvement in the preservation and attractiveness of Malay Culture depicted in the news is a hope that the Malay culture will be maintained and sustainable in the community of the city of Medan despite the stream of globalization.

Keywords: Malay Culture; Mass Media Coverage; Medan City; Online Media

\section{ABSTRAK}

Artikel ini bertujuan untuk menganalisis bingkai pemberitaan media online di Kota Medan tentang Budaya Malay. Identitas kebudayaan Etnik Melayu di Medan bisa ditemui pada beberapa bangunan yang menjadi ikon Kota Medan antara lain Istana Maimon dan Mesjid Raya Al Mahsun yang terletak di pusat Kota Medan. Selain memiliki berbagai ikon yang terkait Melayu, Medan juga merupakan kota dengan penduduk asli bangsa Melayu. Seiring dengan arus globalisasi, Budaya Melayu semakin dikenal luas oleh masyarakat lewat pemberitaan media massa, utamanya media daring di Medan. Penelitian ini dilakukan melalui pendekatan kualitatif dengan paradigma konstruktivis melalui metode analisis framing model Entman. Simpulan dari artikel ini bahwa media daring di Medan dalam hal ini www.medan.tribunnews.com memberikan ruang yang luas dalam memberitakan Budaya Melayu di Medan. Tiga hal yang menjadi temuan yaitu terkait tema-tema pemberitaan, keterlibatan pemerintah dan masyarakat dalam pelestarian serta daya tarik Budaya Melayu yang digambarkan dalam berita menjadi harapan bahwa Budaya Melayu akan tetap terjaga dan lestari di tengah masyarakat Kota Medan meski diterpa arus globalisasi.

Kata Kunci: Budaya Melayu; Kota Medan; Media Online; Pemberitaan Media Massa 


\section{INTRODUCTION}

Medan City is one of the big cities in Indonesia, as the capital city of Sumatera Utara province. It belongs to the three biggest cities in Indonesia, beside Jakarta and Surabaya, and it is also the biggest city in Sumatera Island. One of the ethnics living in Medan City is Malay Ethnic that becomes the part of Malay Sumatera Timur ethnic. Beside Malay, various tribes and ethnicities also live in Medan, such as Bataknese, Javanese, Mandailingnese, Karonese, Minangnese, Acehnese, and the others. Malay in Medan is identical with the name of Malay Deli. It is because Medan City is surrounded by a regency called Deli Serdang. The people of Malay Deli ethnic in Medan City lives various sub- districts such as Medan Deli, Medan Barat, Medan Labuhan, Medan Denai, Medan Timur, Medan Johor, Medan Sunggal, Medan Kota, Medan Tuntungan, Medan Baru and Medan Belawan.

The identity of Malay Ethnic culture in Medan can be found in some buildings that become the icons of Medan City such as Istana (Palace) Maimon and Mesjid Raya (Grand Mosque) Al Mahsun in which both historical buildings are located exactly in the center of Medan City. Besides, in some places in Medan, we can see the houses of the people and the mosques whose shapes and colors are identical with Malay Culture. Then, Malay People in Medan City can be recognized from the special dialects they speak in daily life. One of them is the use of "e" letter in the pronunciation of a word ended with "a" consonant such as "dari mana" becomes "dari mane". It is related to the existence of other ethnics living in Medan City. Then, the use of "e" letter in the dialect spoken daily with different pronunciation in general. However, the meaning is the same with many other Malay Languages. Malay civilization existing today can develop more advanced and even can influence big civilization of the world if Malay ethnic in general can turn the condition from being under hegemony to be a culture with hegemony (Sanusi, 2017). It is because the family of Malay ethnic is not only in Medan City or some other areas in Indonesia, but also in some other countries in South Asia region.

Along with the social changes in the society because of the assimilation of various cultures in Medan, Malay Culture seems to compete in demonstrating its existence and identity amid the society. Through the culture characteristic it has, it should be able to always think hard on keeping it by combining cultural ideas, technology and related institutions (Smaldino, 2019). In addition, with the development of communication technology and the flow of globalization happening today, the cultural symbols of an ethnic get obscure because of being exposed by many kinds of information. The research result of Damanik (2018) states that the people of Medan City are categorized into two ethnicities, namely 'Batak' and 'Malay'. It means that there is identity obscuring happening towards the native inhabitants in Medan City. Nevertheless, the effort to keep sustaining the cultural value of an ethnic or tribe actually has the opportunity to sustain if it benefits mass media that has the ability to spread information to the public, and one of which is through online media.

Generally, research projects related to local culture communication theme is often carried out using ethnography or case study approach that is not related to mass media reality. In fact, local culture themes frequently become the important attention of mass media news especially in local areas. In reporting information, online media must have had its own point of view in perceiving an event to be news that is representative to be read by the readers. Some studies related to local culture news were conducted by online media. For example, Malang Post which is a part of Jawa Post networks usually reports its news using Malang people identity as a part of maintaining local culture even though, in one aspect, it is done as a part that cannot be separated from the economic interest of Malang Post to get and to retain its readers (Andryani. K, 2015). Purwati (2013), based on her research, concludes that media that reports the activities in the local culture approach, gives the opportunities for every party to be able to keep on maintaining the local culture values reported. Muktiyo (2015) explains that there are only a few studies on media product reality related to the local culture values, especially in the relations with the strong commodification process in the flow of globalization and media capitalism. Meanwhile, Afridhita dan Purworini (2016) perceive the role of Solopos.com online media as a part of information delivery related to the conflict in Keraton (Palace) Solo through framing analysis.

Based on the research results above, the researcher is interested in studying the news conducted by www.medan.tribunnews.com presenting the information about Malay Deli Culture in its news report in 2018. The information, amid the challenge of civilization changes, gives a space for Malay culture to always get a place in the mind of the people in Medan because of the mass media function especially online media spread among the people. 
Vera (2016) mentions that there are three big groups that can be seen from a media based on the physical characteristics, namely Printed Media, Electronic Media, and Social Media. Related to the existence of social media, there have been many studies believing that mass media, especially social media, can change life style or local culture in the surrounding, by influencing the way of thinking of a group or certain circle of people in order to like or to follow something new or foreign for them. Meanwhile, the changes occurring can be positive or negative in nature. Through the development of technology, conventional mass communication turns into mass media commonly called as online media. Along with the communication technology advancement, human can interact with the other fellow humans around the world that have already had personal identity and will influence the creation of the new social identity or culture (Farida, 2015).

According to (McQuail, 2000), mass media is the most responsible in influencing the existence of other cultures. It is because mass media basically does not always deliver information in accordance with the existing fact. However, it tends to do construction on the event which is suitable with what the journalist understands. He tries to perceive an information on an event and in accordance with the needs of the media itself. Fishman (Eriyanto, 2011) observes that there are two things related to news or information presented to the public. The first is the existing news is the result of selection process towards information developing and the second is the existing news comes from the creation effort carried out by the journalist himself.

The series of information related to Malay Deli Culture reported by www.medan.tribunnews.com to its readers is not separated from the media business strategy and has gone through reconstruction and selection process towards every information developing so that it gives certain value for the readers. The process happening leads to a concept called framing. Eriyanto (2011) explains that framing is a way to report an event by a media to emphasize certain part, to highlight certain aspect, and to exaggerate the way to tell certain reality or event so that people can remember easily. Anggoro (2014) explains in a simple way that framing is an analysis process to find out the way a media frames a reality (event, actor, group, or anything). The framing has certainly gone through construction process, in which in farming analysis, a reality is interpreted and constructed with certain meaning.

Moss (1999) states that when a media has discourse, it has done cultural construction by setting the fact in certain frame to be information product. This cultural construction is a series of reality construction process captured, set, and spread by media through interpretation and language politics (Eriyanto, 2011). That is why the researcher is interested in studying Malay Deli culture reported in www.medan.tribunnews.com. The local culture reality captured and constructed through news will give a tendency of the meaning when it is received by the people as readers. This research was carried out to find out how online mass media constructs the reality in an event to be news from the local culture issues presentation delivered through the analysis of Robert N. Entman framing model. In this study, there is the defined problems presented by www.medan.tribunnews.com related to the news about Malay Deli Culture by keep on having the prediction or diagnose causes in Malay Deli Culture. Then, it presents the moral judgement defined by the online media and treatment recommendation conducted by www.medan.tribunnews.com towards the information presented about Malay Deli Culture news.

\section{METHODS}

This research was carried out through qualitative approach with constructivism paradigm (Sundari \& Salamah, 2019) through analysis method of Entman (2007) framing model. The analysis of Entman framing model emphasized on the communication text presented by the text creator and regarded as important (Marta et al., 2020) by placing two big dimensions namely the selection on presented issue and emphasis or highlight of certain aspects of the existing reality (Wulandari, 2016). Analysis unit in this research was the news presented by www.medan.tribunnews.com related to Malay Deli culture in Medan City. The primary data in this research were obtained from www.medan.tribunnews.com, while the secondary data were obtained from sources of book, article, journal, and so on. The data collection technique was carried out with methods of observation and documentation. Meanwhile, the data analysis used framing analysis of Robert N. Entman. 


\section{RESULT AND DISCUSSION}

During 2018, Medan.tribunnews.com media often reported anything about Malay Deli culture occurring in Medan City. In this article, the study was carried out towards three news selected in purpose with certain criteria. Based on the study conducted on the three news above, the researcher observed some aspects related to the themes talked about by the media, then about anyone and anything that were involving and were involved in the news, and about how the media described Malay Deli culture through the structure of the language, words, story and the description. In the data presentation and analysis, there were four topics delivered in accordance with Entman framing analysis, namely: define problem, causal interpretation, make moral judgement, and treatment recommendation.

Table 1. News about Malay Deli

(Source: www.medan.tribunnews.com)

\begin{tabular}{|c|c|c|}
\hline No. & News Title & Date of Publication \\
\hline 1 & $\begin{array}{l}\text { Nurdin Wahyudi Kembangkan Orkes Al-Auliya Rentak } \\
\text { Malay (Nurdin Wahyudi Develops Band of Al-Auliya } \\
\text { Rentak Malay) }\end{array}$ & Sunday, 10 Juni 2018 \\
\hline 2 & $\begin{array}{l}\text { Eldin: Mari Lestarikan Seni Budaya Malay Melalui } \\
\text { Lomba Tari dan Berbalas Pantun (Eldin: Let's Sustain } \\
\text { Malay Art and Culture through Dance and Traded } \\
\text { Pantoums) }\end{array}$ & Monday, 23 Juli 2018 \\
\hline 3 & $\begin{array}{l}\text { Ribuan warga saksikan penutupan Gelar Malay } \\
\text { Serumpun (Gemes) } 2018 \text { (Thousands of People Watched } \\
\text { the Closing of Gelar Malay Serumpun (Gemes) 2018) }\end{array}$ & $\begin{array}{l}\text { Wednesday, } 7 \text { November } \\
2018\end{array}$ \\
\hline
\end{tabular}

\section{Framing Structure related to Malay Deli Culture Theme in Medan.tribunnews.com}

The news about Malay Deli Culture published in www.medan.tribunnews.com in 2018 in this study will be elaborated through three news. The first news is about the real Malay descendant who want to sustain their culture. The establishment of Orkes Al-Auliya Rentak Malay since February 10, 2002 by Nurdin Wahyudi was not separated from his observation related to the lack of interest of the young people in sustaining local culture. It was because there were many kinds of music that came into the circle of the youth. So, it influenced their interest towards local culture. As a local artist, Nurdin Wahyudi hoped that by frequently watching Malay performance, the number of young people interested in it also increased, and Malay Culture stayed sustained (Medan.tribunnews.com, 2018b).

Table 2. Analysis of Framing 1

\begin{tabular}{ll}
\hline News Title & $\begin{array}{l}\text { Nurdin Wahyudi Develops Band of Al-Auliya Rentak Malay, published on Sunday } \\
\text { Juni 10,2018. }\end{array}$ \\
Problem defined & $\begin{array}{l}\text { The lack of the interest among the young people in sustaining local culture. } \\
\text { Problem cause } \\
\text { Moral judgement }\end{array}$ \\
$\begin{array}{l}\text { The hope to be the part of Malay culture preservation including pantoum, music and } \\
\text { song. }\end{array}$ \\
Solution/ suggestion & $\begin{array}{l}\text { Nurdin Wahyudi hoped that by frequently watching Malay performance, the number } \\
\text { of young people interested in it also increased, and Malay Culture stayed sustained }\end{array}$ \\
\hline
\end{tabular}

The second news discussed in this study is about the command of Medan's Mayor to e art and Culture of Malay together through competition activities of dance and traded pantoum. The competition activities were held by Culture Department of Medan City in order to celebrate the 428th anniversary of Medan City in Merdeka Walk on July 21-22, 2018. The activities were conducted as an effort to sustain the art and Culture of Malay which was original and grand as native Ethnic in Medan 
City. Through the activities, Malay Culture would never extinct and Malay Ethnic could compete with other ethnics in the world. In addition, it would not be destroyed by the changes of the era.

Furthermore, this activity was expected to be held sustainably so that there would be regeneration of tradition artist, and become a place of coaching and development for new talents (Medan.tribunnews.com, 2018a).

Table 3. Analysis of Framing 2

\begin{tabular}{ll}
\hline News Title & $\begin{array}{l}\text { Eldin: Let's Sustain Malay Art and Culture through Dance and Traded Pantoums, } \\
\text { published Monday, July 23, 2018. } \\
\text { The effort to sustain the art and Culture of Malay which was original and grand as } \\
\text { Pative Ethnic in Medan City. }\end{array}$ \\
Problem cause & $\begin{array}{l}\text { It was in order to sustain Malay Culture, so that it would never extinct and it would } \\
\text { not be destroyed by the changes of the era. }\end{array}$ \\
Moral judgement & $\begin{array}{l}\text { Its goal was that Malay Ethnic could compete with other ethnics in the world. Malay } \\
\text { Culture Preservation was not only the responsibility of a few people, but it also was } \\
\text { collective responsibility. } \\
\text { This activity was expected to be held sustainably so that there would be regeneration } \\
\text { of tradition artist, and become a place of coaching and development for new talents. }\end{array}$ \\
\hline
\end{tabular}

The third news in this discussion is about the activity of Gelar Malay Serumpun (Gemes) 2018. The activity held in Istana (Palace) Maimun in Medan City on November 2-4, 2018, had many participants joining not only from Medan City or Sumatera Utara province, but also from other provinces such as Jakarta and even from neighboring countries like Malaysia, Singapore, Brunei Darusalam, and Thailand. This Gemes activity became one of the steps to introduce art and Culture of Malay to people, especially to young generation. Foreign culture has invaded the daily life of the people and tried to be around in the native culture area of Indonesian Nation, so through the activity, young generation must be able to sustain local native culture. It seemed that there were more young generation paying attention, especially Malay Culture. The continuity of Gemes activity was a part of the effort to invite more local and foreign tourists (Medan.tribunnews.com, 2018c).

Table 4. Analysis of Framing 3

\begin{tabular}{ll}
\hline News Title & $\begin{array}{l}\text { Thousands of people watched the closing of Gelar Malay Serumpun (Gemes) 2018, } \\
\text { published on November 7, 2018. }\end{array}$ \\
$\begin{array}{l}\text { Problem defined } \\
\text { Problem cause }\end{array}$ & $\begin{array}{l}\text { The introduction of art and Culture of Malay to people, especially the young generation. } \\
\text { Foreign culture has invaded the daily life of the people and tried to be around in the } \\
\text { native culture area of Indonesian Nation. }\end{array}$ \\
Moral judgement & $\begin{array}{l}\text { Vice Major of Medan, Akhyar Nasution hoped that there were more young generation } \\
\text { paying attention towards Malay culture because the hope for the sustained Malay culture } \\
\text { in this world was in their hands. }\end{array}$ \\
The continuity of gelar Malay serumpun activity was a part of the effort to invite more \\
Solution/
\end{tabular}$\quad \begin{aligned} & \text { local and foreign tourists. } \\
& \text { suggestion }\end{aligned}$

\section{Malay Culture Theme in Online Media}

The themes appear in the news of medan.tribunnews.com media were the ones that became the signature of Malay Deli Ethnic identity. Generally, the themes that became the objects of the news were among others the themes about the activities of Malay Culture carried out by the government and the people of Medan City. In the first news being analyzed, entitled "Nurdin Wahyudi Develops Band of Al-Auliya Rentak Malay" and published on June 10, 2018, the theme was about Malay art especially music. In the news on July 23, 2018, www.medan.tribunnews.com published news entitled: "Eldin: Let's Sustain Malay Art and Culture through Dance and Traded Pantoums". This news contained the theme on the activities of dance and traded pantoum arts. This theme is related to the effort of Medan City government to sustain Malay culture in this area. The next was the third news entitled "Thousands of People Watched the Closing of Gelar Malay Serumpun (Gemes) 2018", published on November 7, 2018. The news highlights art theme that is also intended to sustain Malay culture values among the people of Medan City in order to invite local and foreign tourists. 
In the news on Malay, www.medan.tribunnews.com media tends to bring out the themes that become the part of daily life of Malay Ethnic people in Medan City. Until now, the city whose Malay identity is very strong maintains the traditional theme, so that the people can still enjoy the food, watch or participate in dance, music and traded pantoum. Through those things, it can be predicted that Malay culture will still get attention among Medan people even though it closely goes with various kinds of culture because of the strong globalization stream nowadays.

\section{The Participation of the Government and the People in Sustaining Malay Culture}

From the news being analyzed, it is found that Malay Culture is still sustained until now by maintaining and holding various activities introducing the aspect of Malay values to the people. Www.medan.tribunnews.com media describes the activities carried out by the government of Medan City and the people to introduce and maintain Malay Culture sides in Medan City. The government involvement in the effort in sustaining Malay Culture was described in the news entitled "Eldin: Let's Sustain Malay Art and Culture through Dance and Traded Pantoums". The news description is that "the performance was held in the effort to sustain Malay Culture art which was original and grand as native ethnic of Medan City and the opening was conducted by Vice Mayor of Medan, Drs. H. T. Dzulmi Eldin S., M.Si., accompanied by Co- Chairman of Regional Representative Council of Medan Iswanda Nanda Ramli, representing Chairman of Regional Representative Council of Medan, Henry Jhon Hutagalung". It is described that the government of Medan City starting from the Mayor to the Chairman of Legislative institution i.e. Regional Representative Council of Medan City also attended and got involved in the activities especially intended to sustain Malay Culture in Medan.

Beside the local government, Malay Culture is also sustained by the people themselves. The news of entitled "Nurdin Wahyudi Develops Band of Al-Auliya Rentak Malay" describes about the people who participated and played the role in maintaining and sustaining Malay culture. Based on the things aforementioned, it can be described that medan.tribunnews.com media puts the narration about the role of the government and the people which is until today they keep and maintain Malay Culture values among the people of Medan City which is exposed by other culture values caused by the globalization stream.

\section{The Attractiveness of Malay Culture}

Mass media has the ability to arrange attractive narration through the language use and words in describing the events. This tendency is carried out by medan.tribunnews.com in explaining the narration of Malay Culture in its news. With attractive description and use of words and language, it is reflected that the value and aspect of Malay Culture is indeed interesting to recognize and to know by many people. For example, in the news entitled "Thousands of People Watched the Closing of Gelar Malay Serumpun (Gemes) 2018”, the media described the storyline of Malay culture festival activity held in Medan in an interesting way. For example, it was described with the sentence of "understanding the difference in the life of Malay people was a pride and invaluable treasure as the real wealth of Malay Culture. The way medan.tribunnews.com narrates can make the readers become as if they can watch the attractive activity even though it is only through the news published online.

\section{CONCLUSION}

The analysis carried out towards the news appearing and published by www.medan.tribunnews.com related to Malay Deli culture describes the activities of the people and the government in Medan in the effort in sustaining and maintaining the Malay culture values in Medan. There are at least three things that can be obtained from the description conducted by the media related to it. Firstly, the common themes popular among the people like Malay special food, dance, music, and traded pantoum become the kinds of Malay Culture which until now get attention among the people in Medan. Secondly, the role of the government with its apparatus in Medan City and the involvement of the people become the key in keeping and maintaining Malay culture existence amid the attack of other values and cultures especially foreign culture that is unavoidable 
because of globalization stream. Thirdly, the role of media in describing the interesting sides of a culture becomes important to attract the attention of many people. To introduce or strengthen Malay Culture value among Medan People, the way the media describes the culture will make the people happy to accept the culture. The information presentation delivered is a part of commodification that was carried out by www.medan.tribunnews.com as a part that cannot be separated from economy and politic of the media.

\section{REFERENCES}

Afridhita, R., \& Purworini, D. (2016). Konstruksi Pemberitaan Mediasi Karaton Kasunanan Surakarta. Jurnal Komunikator, 8(1), 11-28.

Andryani. K. (2015). Budaya, Identitas, dan Media Lokal. Jurnal Komunikasi Profetik, 8(2), 5-14.

Anggoro, A. D. (2014). Media, Politik dan Kekuasaan. Jurnal Aristo, 2(2), 38.

Damanik, E. L. (2018). Menolak Evasive Identity: Memahami Dinamika Kelompok Etnik di Sumatera Utara. Anthropos: Jurnal Antropologi Sosial Dan Budaya, 4(1), 9-22. https://doi.org/10.24114/antro.v4i1.9970

Entman, R. M. (2007). Framing Bias: Media in the Distribution of power. Journal of Communication, 57(1), 163-173. https://doi.org/10.1111/j.1460-2466.2006.00336.x

Eriyanto. (2011). Analisis Framing (Konstruksi, Ideologi, dan Politik Media). Yogyakarta: LKiS.

Farida, F. (2015). Media Tradisional Vs Media Online. AT-TABSYIR: Jurnal Komunikasi Penyiaran Islam, 3(1), 41-66. http://journal.stainkudus.ac.id/index.php/komunikasi

Marta, R. F., Prasetya, A. A., Laurensia, B., Stevani, S., \& Syarnubi, K. L. (2020). Imbalance Identity in E-Sports News Intersectionality on Covid-19 Pandemic Situation. Jurnal ASPIKOM, 5(2), 206. https://doi.org/10.24329/aspikom.v5i2.769

McQuail, D. (2000). Mass Communication Theory (Teori Komunikasi Massa). Diterjemahkan oleh: Agus Dharma dan Aminuddin Ram. Jakarta: Erlangga.

Medan.tribunnews.com. (2018a). Eldin: Mari Lestarikan Seni Budaya Malay Melalui Lomba Tari dan Berbalas Pantun - Tribun Medan. Www.Medan.Tribunnews.Com. https://medan.tribunnews.com/2018/07/23/eldin-mari-lestarikan-seni-budaya-Malay-melaluilomba-tari-dan-berbalas-pantun

Medan.tribunnews.com. (2018b). Nurdin Wahyudi Kembangkan Orkes Al-Auliya Rentak Malay Tribun Medan. Www.Medan.Tribunnews.Com. https://medan.tribunnews.com/2018/06/10/nurdin-wahyudi-kembangkan-orkes-al-auliyarentak-Malay

Medan.tribunnews.com. (2018c). Ribuan Warga Saksikan Penutupan Gelar Malay Serumpun (Gemes) $2018 \quad$ - $\quad$ Tribun Medan. Www.Medan.Tribunnews.Com. https://medan.tribunnews.com/2018/11/07/ribuan-warga-saksikan-penutupan-gemes-2018

Muktiyo, W. (2015). Komodifikasi Budaya Dalam Konstruksi Realitas Media Massa. MIMBAR, Jurnal Sosial Dan Pembangunan, 31(1), 113. https://doi.org/10.29313/mimbar.v31i1.1262

Purwati, E. (2013). Peran Media Dalam Melestarikan Budaya Lokal. Aristo, 1(2), 91-107.

Sanusi, I. (2017). Globalisasi Malay: Peluang dan Tantangan Membangun Identitas Malay dalam Konteks Modernitas. Tarbawiyah Jurnal Ilmiah Pendidikan, 1(02), 39-57. https://doi.org/10.32332/tarbawiyah.v1i02.956

Smaldino, P. E. (2019). Social Identity and Cooperation in Cultural Evolution. Behavioural Processes, 161(November), 108-116. https://doi.org/10.1016/j.beproc.2017.11.015

Sundari, S., \& Salamah, S. (2019). Gatewatching Behind the Beating Case of Ratna Sarumpaet in Tribunnews.com and Detik.com. Komunikator, 11(1). https://doi.org/10.18196/jkm.111017

Vera, N. (2016). Komunikasi Massa. Bogor: Ghalia Indonesia.

Wulandari, T. D. (2016). Pemerintahan Jokowi-Jusuf Kalla Menurut Kacamata 5 Media Massa di Indonesia. Jurnal ASPIKOM, 3(1), 88. https://doi.org/10.24329/aspikom.v3i1.102 